\title{
THE TOURNIQUET IN SURGERY
}

\author{
L. Klenerman, London, England
}

The early development of the tourniquet is bound up with the operation of amputation. It was only about a hundred years ago that the tourniquet was first used in other operations on the limbs. The introduction of the "bloodless field" is a landmark in the development of orthopaedic operative technique, and it is interesting to recall how this came about.

There is evidence that limbs were amputated as far back as the neolithic age, but only since Roman times have various constricting devices been employed to help the control of haemorrhage during amputation. Archigenes and Heliodorus, who practised in Rome at about the time of Celsus, used narrow bands of cloth placed directly above and below the line of incision, each passed two or three times about the limb and tied in a single knot. This mainly controlled the venous bleeding. It was an advance on the practice of Hippocrates, who recommended cutting through the dead limb at a joint, " care being taken not to wound any living part" (Adams 1849).

For the next 1,500 years no significant alteration appears to have been made in this practice. Ambroise Paré in the sixteenth century advocated tying "a strong or broad fillet like that which women usually bind up their haire withall " above the site of amputation (Johnson 1649). This helped to retain the maximum length of skin and muscle for the stump, controlled haemorrhage and reduced pain. The use of a stick to twist the constricting bandage was known to William Fabry of Hilden (1560-1624), although Morell in the siege of Besançon (1674) is often given credit for this (Fig. 1). In a work entitled Currus Triumphalis e Terebintho (1679), James Yonge of Plymouth gave an account of a similar contrivance produced by himself.

\section{SCREW TOURNIQUET}

Jean Louis Petit (1674-1750) (Fig. 4) described his invention of the screw tourniquet (Figs. 2 and 3) before the Academie Royal des Sciences in Paris in 1718. He was the first to use the name tourniquet, which is derived from the French tourner, to turn (Thompson 1942). This was a definite advance because it did not require an assistant to hold the instrument in place and could readily be released. The tourniquet consisted of a strap which passed around the limb and to which the screw portion was attached. When the screw was tightened pressure was brought to bear over the main vessel of the limb by a curved piece fixed to the screw. The screw was first made of wood and later of brass. Various modifications of Petit's apparatus remained in use until the latter part of the nineteenth century. However, during the Crimean War the British Army went back to the simpler variety of strap and buckle tourniquet (Thompson 1942).

\section{LISTERIAN METHODS}

Lister, about 1864, was probably the first surgeon to use the bloodless field for operations other than amputation. He described how his attention had been first directed to this subject when trying to work out a satisfactory method for excision of the wrist joint in tuberculosis, and overcome the profuse bleeding associated with the procedure. "And I found that when the hand was raised to the utmost degree and kept so for a few minutes and then while the clevated position was still maintained, a common tourniquet was applied to the arm being screwed up as rapidly as possible, so as to arrest all circulation in the limb and at the same time avoid venous turgescence, I had practically a bloodless field to operate on and thus gained the double advantage of avoiding haemorrhage and inspecting precisely the part with

VOL. 44 B, NO. 4, NOVEMBER 1962 


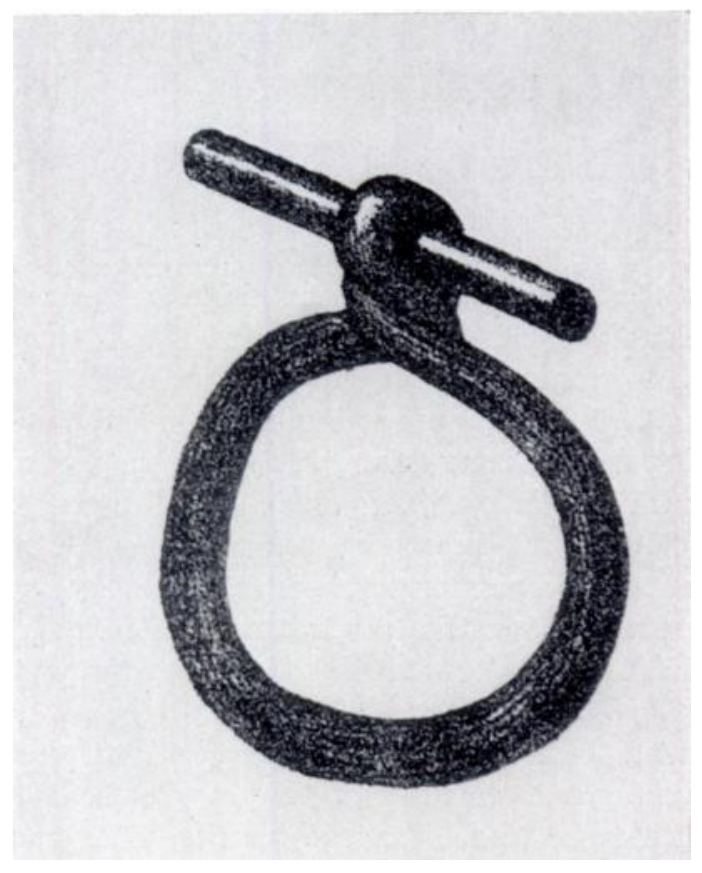

FIG. 1

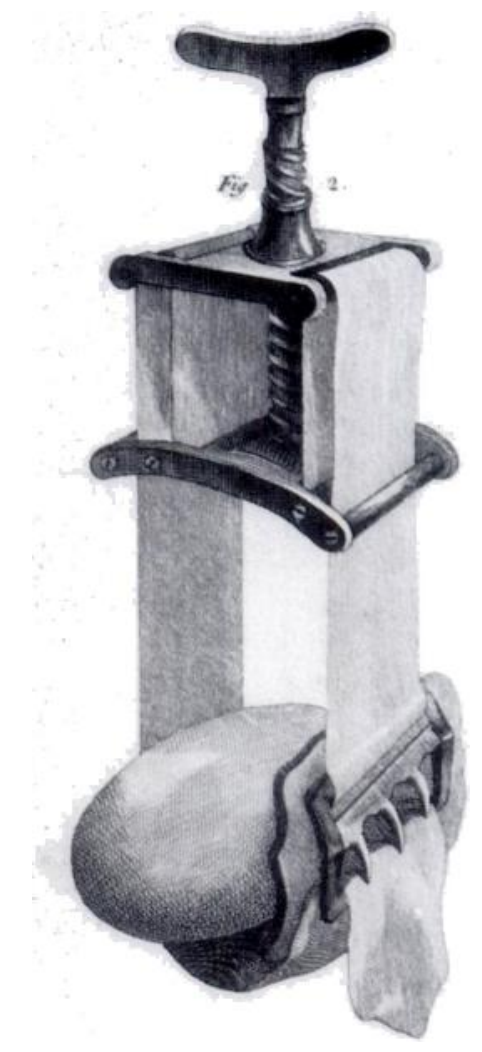

Figure 1-Morell type of tourniquet (Seerig 1838). Figure 2-Petit type of tourniquet (Savigny 1798).

Fig. 2

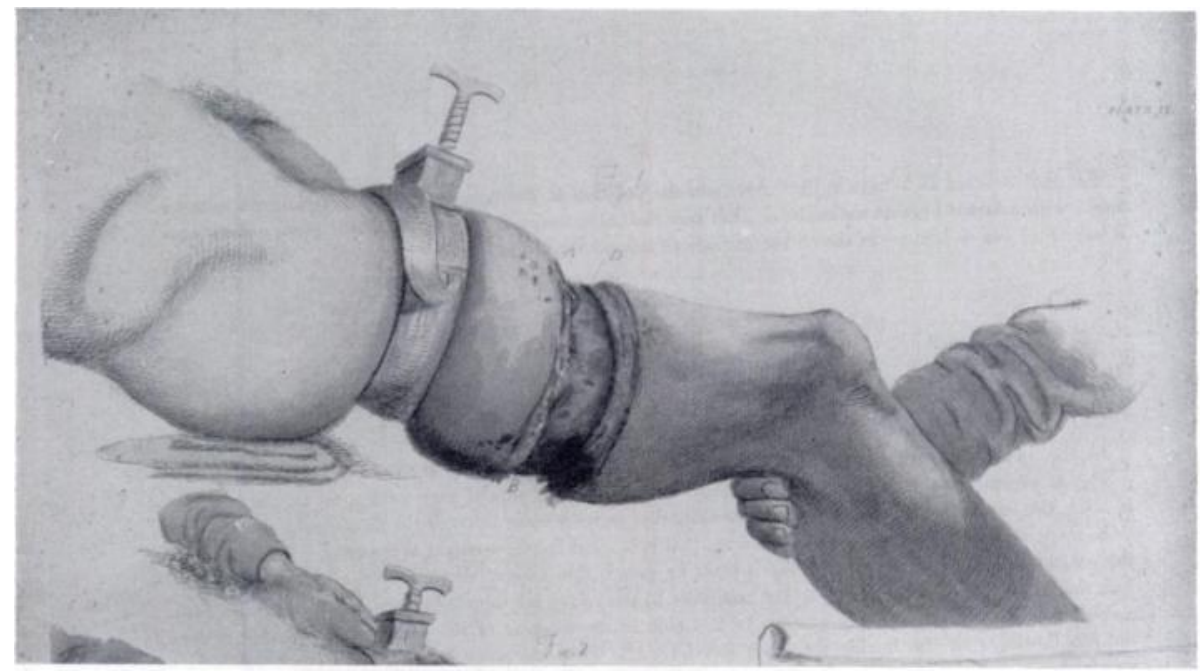

Fig. 3

Illustration from Sir Charles Bell's Illustrations of the Great Operations of Surgery, to show screw tourniquet in place. 
which I was dealing." Lister emphasised the importance of elevation of the limb before the tourniquet was applied and considered four minutes to be the best time. There was thus drainage of all the venous blood and in addition an arteriolar constriction. He gave experimental evidence to prove this point, based on observations on his own hand, and on the exposed metacarpal artery of a horse.

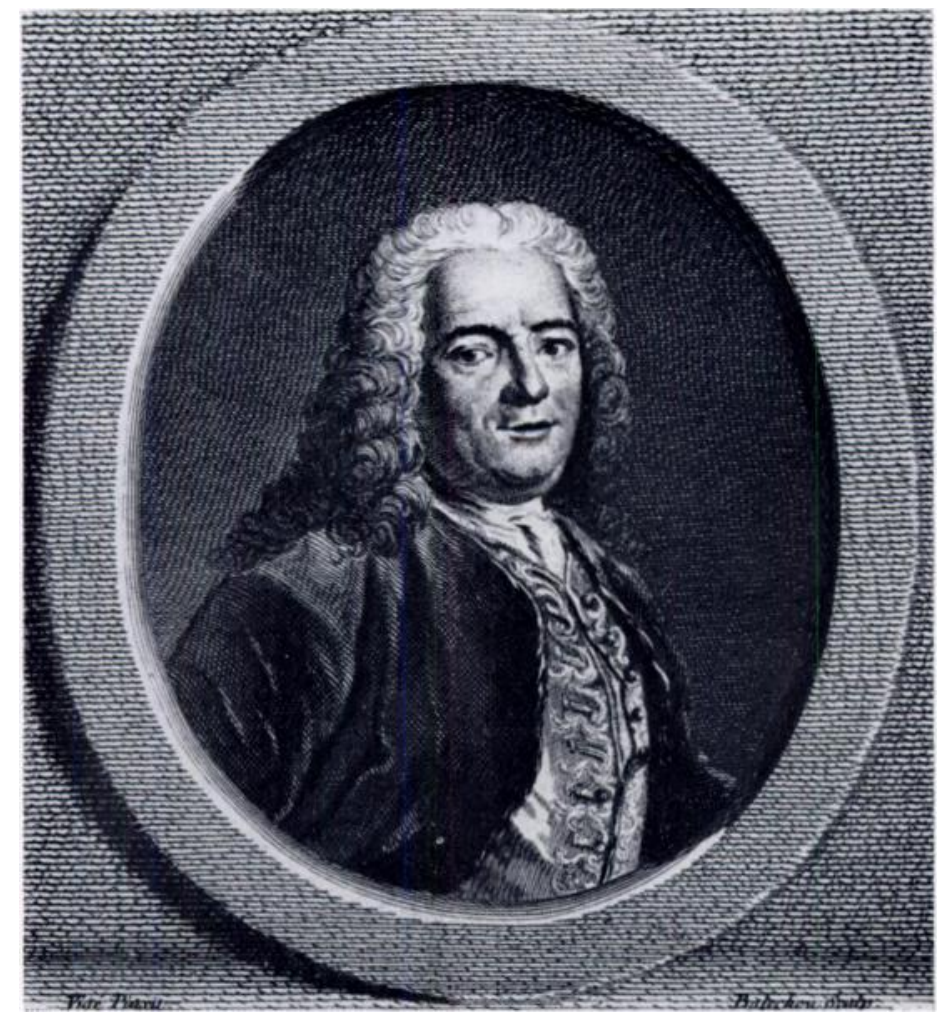

FIG. 4

Jean Louis Petit.

\section{ESMARCH'S BANDAGE}

The commonly used flat rubber bandage which was introduced by Johann Friederich August von Esmarch (Fig. 5), Professor of Surgery at Kiel, was first described by him in 1873. When Esmarch published his method of bloodless operation Lister changed from a tourniquet of the Petit type to Esmarch's rubber one because it was more trustworthy and more convenient, although throughout his practice he continued to empty a limb of blood by simple elevation (Godlee 1924).

Esmarch gave credit to Sartorius (1806), Brunninghausen (1818) and Sir Charles Bell in his book Illustrations of the Great Operations of Surgery (1821) for having used methods of expressing venous blood from a limb in combination with a tourniquet before him. He also acknowledged that Grandesso-Sylvestri in 1871 had used an elastic bandage for emptying a limb of blood before amputation. He himself had been bandaging limbs firmly before amputation since 1855. Esmarch had been stimulated to adopt this method in an effort to conserve blood because he had been disturbed at the amount of blood still present in an amputated limb after it had been severed from the patient. Subsequently he adopted the technique for other operations on the limb. He thus described an operation on a case of osteomyelitis of both tibiae.

VOL. 44 B, NO. 4, NOVEMBER 1962 
" Both legs are then uniformly bandaged from the points of the toes to above the knee with elastic bandages, which are made of woven india-rubber, the uniform compression of which drives the blood out of the vessels of the limb. Immediately above the knee, where the bandage ends, we now apply the india-rubber tubing, well drawn out, four or five times about the thigh and connect one end with the other by means of the hook and brass chain

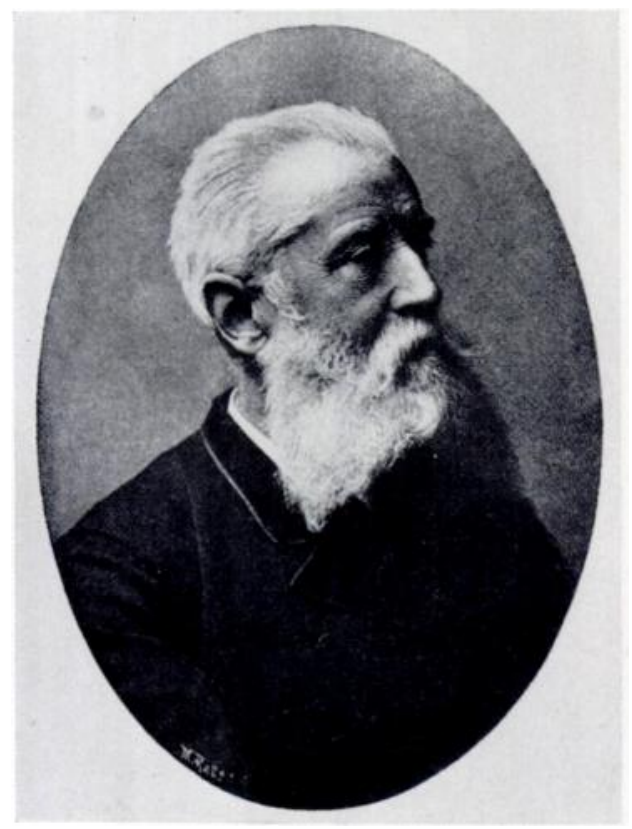

FIG. 5

Johann Friederich August von Esmarch. attached to them respectively. ... We now remove the bandage first applied and see both legs below the tubing resemble those completely of a corpse. You will observe that we operate precisely as in a dead subject."

At this time Esmarch had used the method in about eighty cases and had maintained ischaemia without ill effect for one hour. If, however, the soft tissues contained pus, the tourniquet was applied after elevation of the limb, compression with a rubber bandage being avoided as likely to spread the infection.

\section{THE PNEUMATIC TOURNIQUET}

Harvey Cushing introduced the pneumatic tourniquet to limb surgery in 1904 . He abandoned the rubber tourniquet because it carried the danger of nerve palsy, and it was difficult to remove rapidly and re-apply during an operation. The idea of an inflatable cuff originated from the use of the distensible armlet of the Riva-Rocci blood-pressure apparatus. As this armlet could only be inflated slowly, it allowed the limb to become engorged with blood before finally rendering it ischaemic, and this made dissection difficult. Cushing thus designed a rubber cuff which could be quickly filled by connecting it to a large bicycle pump. As a refinement he suggested inserting a manometer in the tube connecting tourniquet to pump and a tank of compressed air to maintain the required pressure. Cushing also used a pneumatic tourniquet as a constricting band about the head to prevent loss of blood while a skull flap was being raised.

\section{THE TOURNIQUET TODAY}

Today in every reputable operation theatre a regular drill is followed when a tourniquet is used. The pneumatic tourniquet is the instrument of choice for both upper and lower limbs, although there is still a tendency to use Esmarch's bandages as tourniquets on the thigh. With the pneumatic cuff there is measurable control of the pressure exerted on the vessel wall-usually 250-300 millimetres of mercury in an adult-and there is also an even distribution. There are several variations of the sphygmomanometer cuff available.

With the Esmarch's bandage each turn adds to the pressure, and when the turns overlap crushing of a nerve or vessel may occur. Distally placed tourniquets, such as those around the ankle, are unsafe because of lack of soft tissues, and are best avoided. There is, however, a place for the digital tourniquet in combination with local anaesthesia. It is of interest to note that Esmarch recommended "for constriction of a finger, a rubber tube the size of a goose quill will answer."

Haemostasis in a bloodless field-Careful haemostasis has long been a tenet of sound surgery, and this applies equally when operating in a "bloodless field." When practicable-that is 
with the exception of operations on large joints-the tourniquet should be released before the wound is closed. In this way haematomas can be prevented and there is some evidence that there is less pain in the post-operative period. In a fine procedure such as a nerve suture, release of the tourniquet is a vital step before the nerve ends are apposed, because a haematoma at the site of suture would greatly impair the result.

The time limit-Despite its common everyday use, there is a dearth of recorded experimental and clinical evidence for the length of time it is safe to maintain a bloodless field. Two hours is the most generally accepted upper limit, although individual surgeons vary considerably in their views. Some will not exceed one hour. Bunnell (1956) stated that in his experience when the tourniquet time exceeded two hours there was a degree of tissue reaction in the form of local induration at the site of operation. He advised a ten-minute " breathing spell " after an hour and a half, after which the tourniquet could be safely re-applied for a further similar period.

In vascular surgery, when clamps have been kept on the aorta for longer than four hours, ischaemic changes have followed in both lower limbs. Two hours as the longest time for the tourniquet to be in position, with a ten-minute "breathing spell " at one and a half hours, thus seems to be well within the margins of safety.

Experimental work on dogs has shown that the dangers of prolonged tourniquet ischaemia can be prevented by local hypothermia (Paletta, Willman and Ship 1960). This suggests a possible future development in clinical work. Two simple practical suggestions for keeping the limb with a tourniquet cool are the frequent irrigation of the operative field with cold saline and the avoidance of hot spotlights (Bruner 1951).

The tourniquet is also used in dealing with tumours of the limbs. There is evidence that dissemination of tumour emboli is reduced when biopsy or amputation for malignancy is carried out in a "bloodless field" (Peltier 1956). It is also necessary to have a tourniquet for the perfusion of limbs with chemotherapeutic agents (Creech, Krementz, Ryan and Winblad 1958).

\section{HAZARDS OF THE TOURNIQUET IN PRACTICE}

Rerauce of the care taken and the widecnread uce of the nnellmatic ouff comnlicatinne 
Bunnell, S. (1956): Surgery of the Hand. Third edition, p. 90. London: Pitman Medical Publishing Company Ltd.

Creech, O., Jun., Krementz, E. T., Ryan, R. F., and Winblad, J. N. (1958): Chemotherapy of Cancer: Regional Perfusion Utilizing an Extracorporeal Circuit. Annals of Surgery, 148, 616.

Cushing, H. (1904): Pneumatic Tourniquets: with Especial Reference to their Use in Craniotomies. Medical News, 84, 577.

Ескноғ, N. L. (1931): Tourniquet Paralysis: A Plea for the Extended Use of the Pneumatic Tourniquet. Lancet, ii, 343.

EsmarCh, J. F. A. von (1873): Ueber künstliche Blutleere bei Operationen. Sammlung Klinischer Vorträge in Verbindung mit Deutschen Klinikern, Chirurgie 19, No. 58, p. 373.

Esmarch, J. F. A. (1878): The Surgeon's Handbook on the Treatment of Wounded in War, p. 127. English translation by H. H. Clutton. London: Sampson Low, Marston, Searle \& Rivington.

Fine, J., Frank, H. A., and Seligman, A. M. (1944): Traumatic Shock. VIII. Studies in the Therapy and Hemodynamics of Tourniquet Shock. Journal of Clinical Investigation, 23, 731.

FIRST AID (1958): Authorised manual of The St John Ambulance Association of the Order of St John, The St Andrew's Ambulance Association, and The British Red Cross Society, p. 49.

GodleE, Sir Rickman John (1924): Lord Lister. Third edition, p. 632. Oxford: at the Clarendon Press.

Grifriths, D. Ll. (1950): In Modern Trends in Orthopaedics, p. 359. Edited by Sir H. Platt. London: Butterworth \& Co. (Publishers) Ltd.

Harvey, S. C. (1929): The History of Haemostasis. New York: Paul Hoeber Incorporated.

Johnson. T. (1649): The Workes of that famous Chirurgion Ambrose Parey, p. 339. London: Richard Cotes and Willi: Du-gard.

Lister, Joseph, Baron (1909): Collected Papers. Volume I, p. 176. Oxford: at the Clarendon Press.

Moldaver, J. (1954): Tourniquet Paralysis Syndrome. Archives of Surgery, 68, 136.

Paletta, F. X., Willman, V., and Ship, A. G. (1960): Prolonged Tourniquet Ischemia of Extremities. An Experimental Study on Dogs. Journal of Bone and Joint Surgery, 42-A, 945.

Peltif, L. F. (1956): Fat Embolism. The Prophylactic Value of a Tourniquet. Journal of Bone and Joint Surgery, 38-A, 835.

Savigny, J. H. (1798): A Collection of Engravings. The Most Modern and Approved Instruments used in The Practice of Surgery. The Letter-Press by T. Bensley.

Scotт, J. H. S. (1955): Traumatic Aneurysm of the Peroneal Artery. Journal of Bone and Joint Surgery, 37-B, 439.

Seddon, H. J. (Editor) (1954): Peripheral Nerve Injuries by the Nerve Injuries Committee of the Medical Research Council. London: Her Majesty’s Stationery Office.

Seerig, A. W. H. (1838): Armamentarium Chirurgicium. Breslau: A. Gosohorsky.

TAYLOR, Lord (1960): First Aid in the Factory, p. 36. London: Longmans.

Thомpson, C. J. S. (1942): The History and Evolution of Surgical Instruments, p. 85. New York: Schumans.

WALlis, F. C. (1901): Treatment of paralysis and muscular atrophy after the prolonged use of splints or of an Esmarch's cord. Practitioner, 67, 429.

Watson-Jones, Sir R. (1952): Fractures and Joint Injuries. Fourth edition, Volume I, p. 121. Edinburgh and London: E. \& S. Livingstone Ltd.

Watts, J. C. (1962): Professor of Military Surgery, Royal Army Medical College, London. Personal communication.

Webb-Jones, A. (1955): Aneurysm after Foot Stabilisation. Journal of Bone and Joint Surgery, 37-B, 440.

Yonge, J. (1679): Currus Triumphalis e Terebintho. London: J. Martyn. 